\title{
Dynamic System Modeling in the Selection of Regency Road Pavement Construction Types
}

\author{
A R Indra Tjahjani \\ Civil Engineering Department \\ Pancasila University \\ South Jakarta, Indonesia \\ arindratjahjani@univpancasila.ac.id
}

\author{
Nuryani Tinumbia \\ Civil Engineering Department \\ Pancasila University \\ South Jakarta, Indonesia \\ nuryani@univpancasila.ac.id
}

\author{
Wita Meutia \\ Civil Engineering Department \\ Pancasila University \\ South Jakarta, Indonesia \\ wita.meutia@univpancasila.ac.id
}

\begin{abstract}
The selection of pavement construction type is influenced by several factors, such as technical conditions, economic conditions and conditions in the area. These factors have different criteria in each region, resulting in a different selection of road pavement. This paper aims to model the most suitable pavement type in an area. Types of pavement designed in this paper are flexible pavement, rigid pavement and penetration pavement. The research areas in this paper are those that represent develop regions (Central Java), developing regions (West Kalimantan), and regions that will develop (East Nusa Tenggara) with a focus on district roads. Methods used in this paper are descriptive analysis based on secondary data and literature studies to build a model for selecting pavement types which can later be further analyzed using a dynamic system.
\end{abstract}

Keywords: dynamic system, pavement, road length, causal loop, topography

\section{INTRODUCTION}

The policy and strategy for 2015-2019 Medium-Term Development Plan (RPJM) is to accelerate the development of border areas in various fields, especially economic, social and security, and to make the border region as an integrated and environmental-friendly gateway for economic and trade activities with neighbouring countries. To accelerate development of the border area, a strategy was adopted; such as building connectivity from the main transportation hub of the national strategic activity center to villages in the priority border location with surrounding sub-districts, regional activity centers (district capital), national activity centers (provincial capitals) and connecting with neighbouring countries, and also build connectivity through sea transportation services to improve the quality and intensity of services to the border region. The second RPJM in 20102014 has predicted that the length of district road needed is almost 498,687 km, meaning that the role of decentralization and regional autonomy is crucial in the administration of regional roads. The number of vehicles utilizing district roads is generally in the low-moderate category (ranging from no more than 1000 vehicles per day), which is indicated by a range of road widths of 3.0 to 7.0 meters. Along with the development, economic equality is expected to occur in each region. Until now, the selection process of pavement construction for the state, provincial and district/city roads is still based on the strength of the soil, traffic volume and vehicle load. In choosing the pavement type, factors that usually become the variable are traffic volume, design life, and soil bearing capacity. However, there has never been a selection of district road pavement construction types that relate to the development of budget allocation by the district government. Thus this research aims to provide a recommendation for the type of pavement that suits the needs of the conditions of an area.

\section{LITERATURE REVIEW}

Road pavement designs in developing countries which are usually based on industrialized countries can be irrelevant because they are not economically feasible. That is because there are significant differences in socioeconomic conditions between the two. The study of optimal pavement design and its relationship to the development stage of a country results in the optimal trade-off between initial financing for construction and subsequent maintenance depending on the stage of economic development [1].

Many researchers have developed studies on road construction models with several variables including soil and material properties, traffic loads, climate factors, and unit prices [2]; traffic loading, loop of economics, loop of pavement design, maintenance options [3]; low income, penalty cost, population, fuel price, residential location [4]. The study of the proposed policy model for construction type and district road width by taking into account regional potential has been carried out before. The district road pavement selection model was then developed using the Analytical Hierarchy Process (AHP) method based on regional economic conditions [5]. Variables used include pavement types, road construction budget allocations, subgrade strength, topography, vehicle loads, and economic growth. The same variable is done by the econometric method to see simultaneous equations based on the dominant variable [6]. Mathematical models are built using the Simultaneous Equation Method through Cobb-Douglas theory [7]. From the AHP method, a Matrix and Nomogram are produced that shows the relationship between the Road Length and the Type of Pavement and the percentage of GRDP that can be used by district decision-makers in making decisions to determine the type of pavement to be selected based on local conditions.

The dynamic system is a computer simulation model that helps users to learn complex dynamics in planning decisions effectively [8]. The dynamic system model is an approach to parse complex problems which can analyze causal relationships (between stocks, flows and feedbacks loops) so that they can describe the almost real conditions of an 
environment. Besides this model is also object-oriented simulation use and has been used widely both in the industry [9], and civil engineering [10] [11].

\section{Methodology}

This study uses existing theoretical approaches and then constructs the variables forming the type of road pavement based on the theory. Based on previous research [12], there are three caused components, such as technical, regional condition, and economic condition. Technical consists of soil bearing capacity, traffic, and vehicle load variable; regional condition consists of population, road length, topography, and accessibility variable; economic condition consists of regional economic activity, \%GDRP of the transportation sector and local government budget allocation for development. The relationship between the three components is shown in following Fig. 1 below.

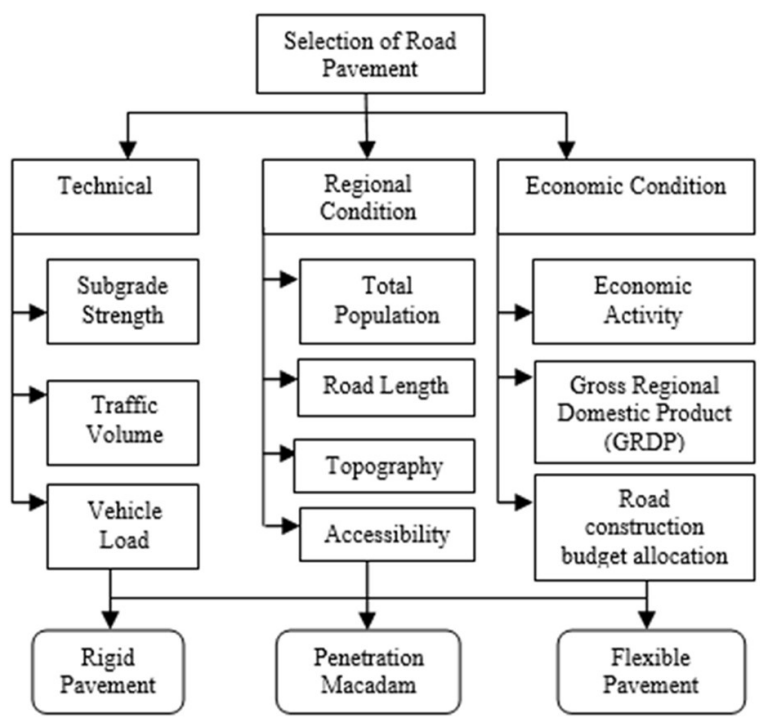

Fig. 1. Scheme of selection of road pavement construction types [12]

The variables of each three conditions are proceed by The Analytic Hierarchy Process (AHP) method. Thus, there are only a few variables have got the highest weighting that constructs the model of the selection of road pavement types model, such as:

- Total population

- Topography

- Accessibility

- Road length

- GDRP

Furthermore, the variables obtained are formed into a model that will be analyzed using a Dynamic System. The data used in this study are secondary. The calculation model is performed using a Dynamic Systems approach; using the Pavement Type equation $\left(\mathrm{X}_{1}\right)$ that has been developed [12]:

$$
\begin{gathered}
X_{1}=a+b_{6} * \text { total population }+b_{7} * \text { topography }+ \\
b_{8}^{*} \text { accesibility }+b * \text { road length }+\mu
\end{gathered}
$$

And equation:

$$
\hat{Y}=f(\text { pavement type })+f(\% G R D P)
$$

Or in trans-log:

$$
\ln \hat{Y}=\ln \text { pavement type }+\ln \% \text { GRDP }
$$

Where:

$\begin{array}{ll}\text { total population } & \mathrm{b}_{6}=7.333868119127 \mathrm{E}-07 \\ \text { topography } & \mathrm{b}_{7}=0.4396737 \\ \text { accessibility } & \mathrm{b}_{8}=0.1150738 \\ \text { the length of built up road } & \mathrm{b}=0.0026773\end{array}$

The following Fig. 2 is a Causal Loop Diagram illustrating the relationship of variables in determining the type of pavement and Fig. 3 shows its stock and flow diagram.

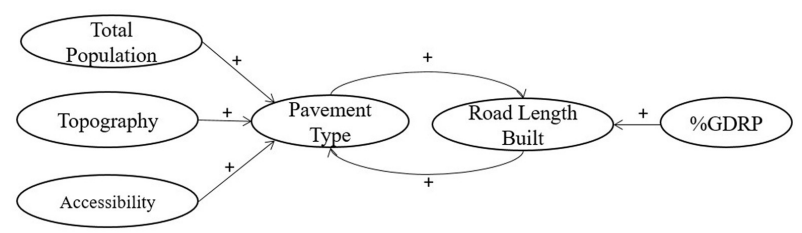

Fig. 2. Causal Loop Diagram.

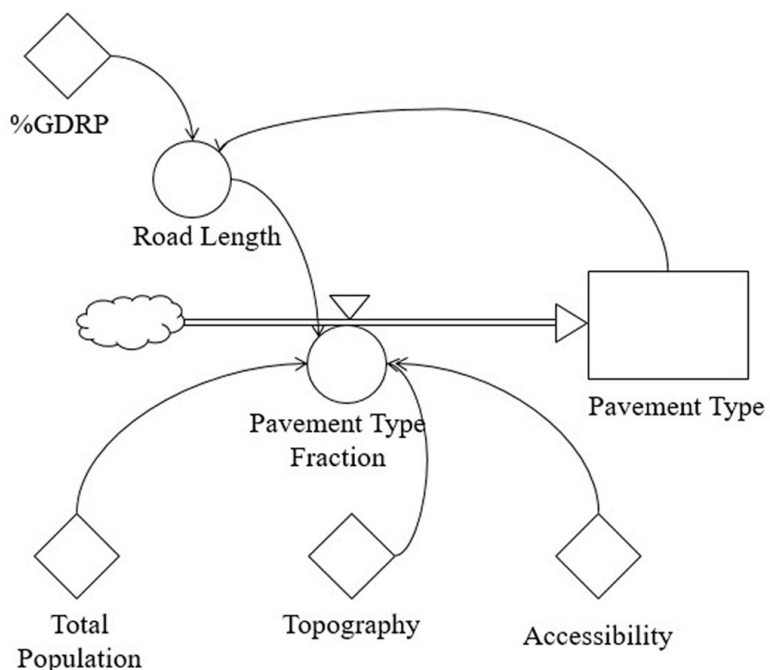

Fig. 3. Stock and Flow Diagram.

\section{RESULTS}

This study uses secondary data on population, topography, GRDP, accessibility and length of district roads. There are 61 regencies from the provinces of East Nusa Tenggara, Central Java and West Kalimantan, which are used as input models.

For data processing, the variables used are grouped according to the type of data i.e. district population data, topography is categorized into 6 classes ( $1=$ flat; $2=$ bumpy; $3=$ sloping; $4=$ rather steep; $5=$ steep; $6=$ very steep), 
accessibility ( $0=$ accessible; $1=$ inaccessible), GRDP and road length obtained from Statistics Indonesia (BPS).

Model simulations are carried out using Powersim software. The following TABLE I shows the type of pavement that can be applied to local roads in 61 districts (East Nusa Tenggara, Central Java and West Kalimantan) based on input variables in the model.

TABLE I. Modelling ResUlts USING DyNAMIC System

\begin{tabular}{|c|c|c|c|c|c|c|c|c|}
\hline No & Districts & $\begin{array}{c}\text { Total } \\
\text { population } \\
\text { (people) }\end{array}$ & $\begin{array}{l}\text { Topography } \\
\text { type }\end{array}$ & Accesibility & $\begin{array}{l}\text { GRDP } \\
(\%)\end{array}$ & $\begin{array}{c}\text { Road length } \\
\text { built (km) }\end{array}$ & $\begin{array}{c}\text { Pavement } \\
\text { Type }\end{array}$ & $\begin{array}{l}\text { Predicted Road } \\
\text { Length (km) }\end{array}$ \\
\hline 1 & Alor & 212793 & 4 & 1 & 4 & 0 & 3 & 0 \\
\hline 2 & Belu & 402825 & 3 & 1 & 5 & 0 & 1 & 6.6196 \\
\hline 3 & Ende & 254845 & 3 & 1 & 4 & 0 & 1 & 4.5762 \\
\hline 4 & East Flores & 274737 & 1 & 0 & 5.6 & 0 & 1 & 7.84564 \\
\hline 5 & Kupang & 330322 & 2 & 1 & 5.2 & 76 & 1 & 7.02828 \\
\hline 6 & Lembata & 127590 & 1 & 0 & 6.5 & 0 & 1 & 9.6847 \\
\hline 7 & Manggarai & 314224 & 3 & 1 & 4.8 & 0 & 1 & 6.21092 \\
\hline 8 & West Manggarai & 255277 & 1 & 0 & 4.7 & 0 & 1 & 6.00658 \\
\hline 9 & East Manggarai & 263142 & 1 & 0 & 5 & 9.71 & 1 & 6.6196 \\
\hline 10 & Ngada & 162984 & 4 & 1 & 6 & 5 & 3 & 1.4682 \\
\hline 11 & Nagekeo & 154168 & 3 & 1 & 4 & 0 & 3 & 0 \\
\hline 12 & Rote Ndao & 151937 & 1 & 0 & 7 & 80.03 & 1 & 10.7064 \\
\hline 13 & Sabu Raijua & 85321 & 1 & 0 & 6 & 0 & 1 & 8.663 \\
\hline 14 & Sikka & 315582 & 1 & 0 & 4 & 32.96 & 1 & 4.5762 \\
\hline 15 & West Sumba & 145575 & 4 & 1 & 5 & 0 & 3 & 0 \\
\hline 16 & Southwest Sumba & 367771 & 2 & 1 & 4 & 0 & 2 & 0.9788 \\
\hline 17 & Central Sumba & 82999 & 4 & 1 & 5.6 & 0 & 3 & 0.65084 \\
\hline 18 & East Sumba & 241822 & 3 & 1 & 4.8 & 0 & 3 & 0 \\
\hline 19 & Central South Timor & 461555 & 3 & 1 & 4.6 & 0 & 3 & 0 \\
\hline 20 & Central North Timor & 264106 & 4 & 1 & 4.6 & 6.25 & 3 & 0 \\
\hline 21 & Banjarnegara & 923971 & 6 & 1 & 5 & 0 & 3 & 0 \\
\hline 22 & Banyumas & 1551076 & 1 & 0 & 5.6 & 0 & 1 & 7.84564 \\
\hline 23 & Batang & 886476 & 6 & 1 & 5.7 & 0 & 3 & 0.85518 \\
\hline 24 & Blora & 760799 & 1 & 0 & 5.2 & 0 & 1 & 7.02828 \\
\hline 25 & Boyolali & 932814 & 5 & 1 & 6.1 & 0 & 3 & 1.67254 \\
\hline 26 & Brebes & 1764041 & 4 & 1 & 4 & 0 & 3 & 0 \\
\hline 27 & Cilacap & 166586 & 1 & 0 & 4.9 & 0 & 3 & 0 \\
\hline 28 & Demak & 1064475 & 1 & 0 & 5.9 & 0 & 2 & 4.86126 \\
\hline 29 & Grobogan & 1179448 & 1 & 0 & 5.2 & 0 & 2 & 3.43088 \\
\hline 30 & Jepara & 1137608 & 1 & 0 & 5 & 0 & 2 & 3.0222 \\
\hline 31 & Karanganyar & 744965 & 4 & 1 & 5.2 & 0 & 3 & 0 \\
\hline 32 & Kebumen & 1301590 & 1 & 0 & 6 & 0 & 1 & 8.663 \\
\hline 33 & Kendal & 948493 & 1 & 0 & 4.9 & 0 & 1 & 6.41526 \\
\hline 34 & Klaten & 1156043 & 3 & 1 & 5.3 & 0 & 2 & 3.63522 \\
\hline 35 & Kudus & 743291 & 1 & 0 & 5.1 & 0 & 2 & 3.22654 \\
\hline 36 & Magelang & 1129490 & 1 & 0 & 4.9 & 0 & 2 & 2.81786 \\
\hline 37 & Pati & 1092230 & 1 & 0 & 5.4 & 0 & 2 & 3.83956 \\
\hline 38 & Pekalongan & 886478 & 6 & 1 & 6.5 & 0 & 3 & 2.4899 \\
\hline 39 & Pemalang & 1493454 & 1 & 0 & 4.3 & 0 & 1 & 5.18922 \\
\hline 40 & Purbalingga & 907526 & 7 & 1 & 6.5 & 0 & 3 & 2.4899 \\
\hline 41 & Purworejo & 738728 & 4 & 1 & 6.1 & 0 & 3 & 1.67254 \\
\hline 42 & Rembang & 598318 & 1 & 0 & 6.4 & 0 & 2 & 5.88296 \\
\hline 43 & Semarang & 987177 & 7 & 0 & 4.6 & 0 & 2 & 2.20484 \\
\hline 44 & Sragen & 741142 & 4 & 1 & 6.3 & 0 & 1 & 9.27602 \\
\hline 45 & Sukoharjo & 741366 & 1 & 1 & 5.9 & 0 & 1 & 8.45866 \\
\hline 46 & Tegal & 1379489 & 1 & 1 & 4.8 & 0.46 & 1 & 6.21092 \\
\hline 47 & Temanggung & 719553 & 4 & 1 & 4.5 & 0 & 1 & 5.5979 \\
\hline 48 & Wonogiri & 842708 & 3 & 1 & 4.5 & 0 & 1 & 5.5979 \\
\hline 49 & Wonosobo & 810323 & 4 & 1 & 4.8 & 0 & 3 & 0 \\
\hline 50 & Bengkayang & 266741 & 4 & 1 & 4.5 & 0 & 3 & 0 \\
\hline 51 & Kapuas Hulu & 242795 & 2 & 1 & 4.5 & 0 & 1 & 5.5979 \\
\hline
\end{tabular}




\begin{tabular}{|c|c|c|c|c|c|c|c|c|}
\hline No & Districts & $\begin{array}{c}\text { Total } \\
\text { population } \\
\text { (people) }\end{array}$ & $\begin{array}{c}\text { Topography } \\
\text { type }\end{array}$ & Accesibility & $\begin{array}{c}\text { GRDP } \\
(\%)\end{array}$ & $\begin{array}{l}\text { Road length } \\
\text { built (km) }\end{array}$ & $\begin{array}{c}\text { Pavement } \\
\text { Type }\end{array}$ & $\begin{array}{l}\text { Predicted Road } \\
\text { Length (km) }\end{array}$ \\
\hline 52 & North Kayong & 124935 & 2 & 1 & 4.4 & 0 & 1 & 5.39356 \\
\hline 53 & Ketapang & 544309 & 2 & 1 & 4.9 & 0 & 1 & 6.41526 \\
\hline 54 & Kubu Raya & 566394 & 2 & 1 & 5.2 & 12.67 & 1 & 7.02828 \\
\hline 55 & Landak & 388840 & 4 & 1 & 5.1 & 0 & 3 & 0 \\
\hline 56 & Melawi & 222932 & 4 & 1 & 5.3 & 0 & 3 & 0.03782 \\
\hline 57 & Pontianak & 294623 & 2 & 1 & 5.1 & 0 & 1 & 6.82394 \\
\hline 58 & Sambas & 622757 & 2 & 1 & 5.3 & 0 & 1 & 7.23262 \\
\hline 59 & Sanggau & 467080 & 2 & 1 & 3.2 & 0 & 1 & 2.94148 \\
\hline 60 & Sekadau & 209381 & 2 & 1 & 3.5 & 0.37 & 1 & 3.5545 \\
\hline 61 & Sintang & 393755 & 4 & 1 & 5.1 & 0 & 1 & 6.82394 \\
\hline
\end{tabular}

Based on the results obtained, the formulation that has been developed can be simulated using Dynamic System modelling.

\section{CONCLUSIONS AND RECOMMENDATIONS}

The analysis shows that there is a relationship between pavement type selection, road length built, and\% the GRDP; which is presented in the form of Dynamic System modelling based on the road selection formulation developed.

A dynamic system model for selecting pavement types needs to be developed by simulating factors such as population growth and increasing GRDP for the next few years.

\section{ACKNOWLEDGMENT}

The implementation of research activities in this paper was funded by the Pancasila University Internal Research Scheme in 2019.

\section{REFERENCES}

[1] K. Tsunokawa, Riaz-ul-Islam, and G. Changyu, "Optimal strategies for highway pavement management in developing countries," Comput. Civ. Infrastruct. Eng., 2002.

[2] S. Tighe, R. Fung, and T. Smith, "Concrete Pavements in Canada: State-of-the-Art Practice," in 7th International Conference on Concrete Pavements, 2001.

[3] K. Tsunokawa and R. Ul-Islam, "Optimal pavement design and maintenance strategy for developing countries: An analysis using HDM-4,” Int. J. Pavement Eng., 2003.

[4] C. Davis and M. K. Jha, "Modeling the effects of socioeconomic factors in highway construction and expansion," J. Transp. Eng., 2009.

[5] W. Wangsadinata, A. R. I. Tjahjani, and Najid, "Road Selection Pavement Type Based on Regional Economic Conditions (in Indonesian)," in The 17th FSTPT International Symposium, Jember University, 2014, pp. 798-806.

[6] A. R. I. Tjahjani, "Determination of Road Pavement Type by Econometrics Method," in Civil Engineering National Seminar V 2015 - UMS, 2015, pp. 109-115.

[7] A. R. I. Tjahjani and V. A. Pratama, "Mathematical Model for the Selection of Regency Road Pavement Types with the Econometrics Method (in Indonesian)," in Civil Engineering National Conference 12, 2018, pp. 75-83.

[8] J. D. Sterman, Business Dynamics : Systems Thinking. 2000.

[9] J. Suprianto and E. Suryani, "Development of Dynamic System Model of Fulfilling Rice Logistics to Keep Rice Stability (Case Study: East Java Province) (in Indonesian)," Sisfo, 2014.

[10] Y. Xu, M. J. Skibniewski, Y. Zhang, A. P. C. Chan, and J. F. Y. Yeung, "Developing a concession pricing model for PPP highway projects,” Int. J. Strateg. Prop. Manag., 2012.
[11] I. P. A. Wiguna, N. Anwar, and H. T. Tjendani, "Development of Dynamic System Models in Determining the Duration of Performance Based Contracts Based On Government Pay Offs And Contractor (in Indonesian)," in Civil Engineering National Conference 12, 2018, pp. 29-38.

[12] A. R. I. Tjahjani, "Election of Regency Road Development Based on Regional Conditions Iin Indonesian)," Dissertation, Civil Engineering Doctoral Program, Tarumanagara University, 2015. 